\section{CITAÇÃO}

Deus, H. M. \& Fonseca, P.(2021)

Modelação Análoga,

Rev. Ciência Elem., V9(03):059.

doi.org/10.24927/rce2021.059

\section{EDITOR}

João Nuno Tavares

Universidade do Porto

\section{EDITOR CONVIDADO}

Paulo Fonseca

Universidade de Lisboa

\section{RECEBIDO EM}

10 de setembro de 2021

\section{ACEITE EM}

10 de setembro de 2021

\section{PUBLICADO EM}

15 de outubro de 2021

\section{COPYRIGHT}

(C) Casa das Ciências 2021

Este artigo é de acesso livre, distribuído sob licença Creative

Commons com a designação

CC-BY-NC-SA 4.0, que permite a utilização e a partilha para fins não comerciais, desde que citado o autor e a fonte original do artigo.

\title{
Modelação Análoga
}

in casadasciencias.org/banco-imagens

Podemos correr montes e vales com os alunos, cativando-os para a geodiversidade local, sem que eles alguma vez nos questionem sobre as estruturas geológicas que se escondem debaixo dos seus pés. Complementando aquilo que se aprende no campo, a modelação análoga é uma metodologia com um valor didático excecional, pois, em sala de aula, é possível modelar os processos geológicos que originaram os afloramentos observados no campo. Também é possível ter uma visão tridimensional das estruturas que se estão a formar em profundidade e da sua relação com as estruturas que se vão formando à superfície, levando sempre em conta a variável tempo e a sua irreversibilidade. Para os alunos, esta fotografia conta uma história que eles bem conhecem, pois foram eles que depositaram, cuidadosamente, aquela sequência de areias coloridas (inicialmente na horizontal), aplicaram as forças para gerar as figuras de deformação, viram as geometrias a mudarem à medida que os materiais foram acomodando (ou não) a deformação e decidiram quando começar este ensaio ou quando parar para tirar esta fotografia.

Helena Moita de Deus

Escola Secundária Seomara da Costa Primo
Geologia é a Ciência que estuda os processos naturais no nosso planeta os quais podem ser muito lentos, na ordem dos milhões de anos (formação de uma cadeia de montanhas), a quase instantâneos (num sismo) e estendem-se, por centenas ou milhares de quilómetros. Estes processos são imprevisíveis, difíceis de presenciar - no geral ocorrem a grandes profundidades - e assim, pelas suas velocidades e extensão é necessário simulá-los para melhor os estudar e entender. A simulação dos processos geológicos, utilizando materiais que têm um comportamento semelhante ao dos naturais ao longo do tempo (materiais análogos), é um método usado desde o séc. XIX - Modelação Análoga. Depois da observação das estruturas no campo, selecionam-se as variáveis da simulação do processo geológico desejado. Assim no ensino e na investigação científica, constroem-se modelos com materiais que podem ser simples e acessíveis como esferovite, madeira, areias coloridas, plasticinas e pós de pedra ou alimentares e de fácil execução. A imagem representa um modelo análogo, com areias coloridas. Costa Vicentina - ZSP.

Paulo Fonseca

Geologia/Universidade de Lisboa

rce.casadasciencias.org

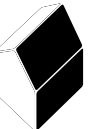




\section{REVISTA DE CIÊNCIA ELEMENTAR}

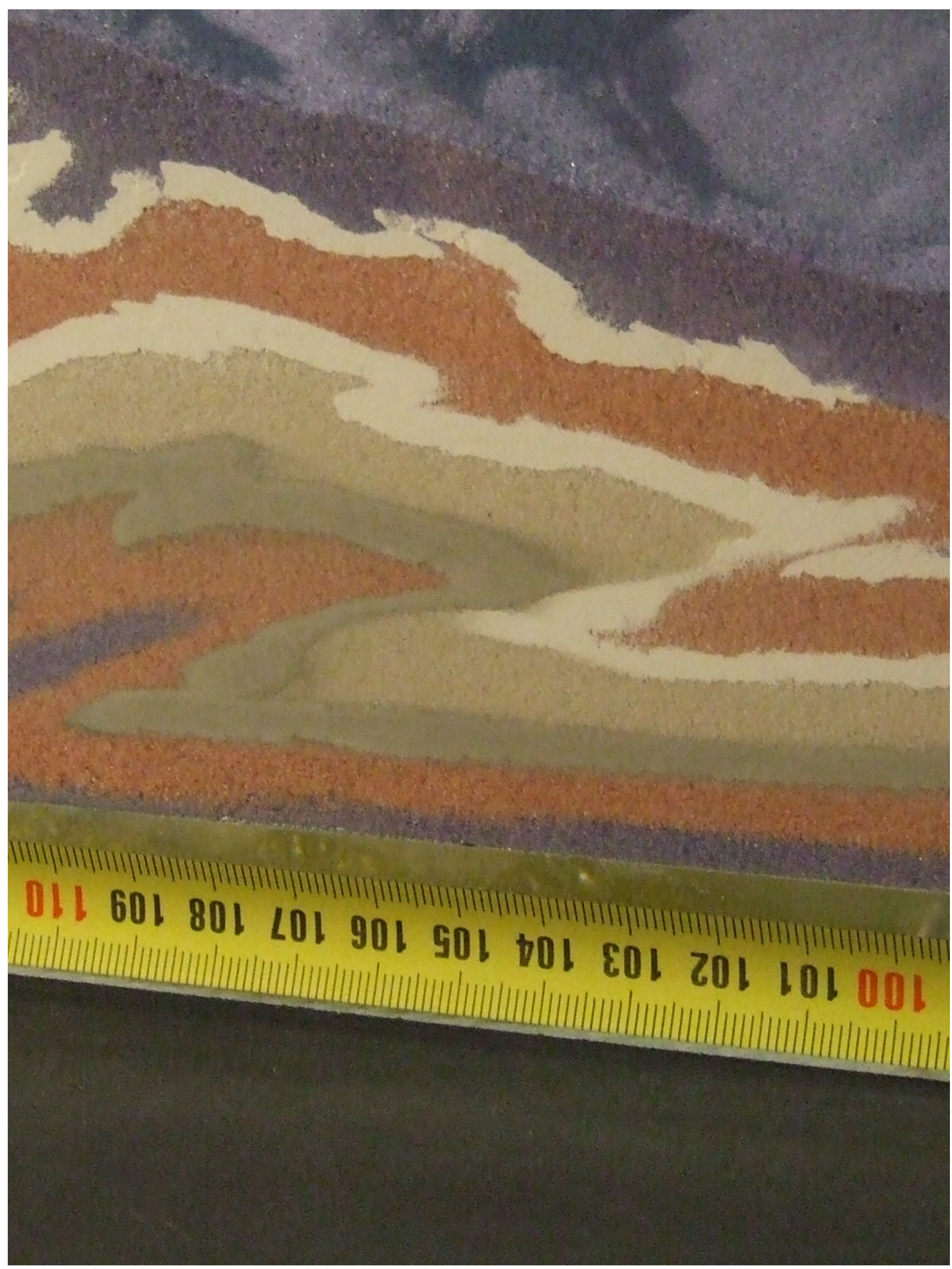

